\title{
INFLUENCE OF NUTRITIONAL STRESS AND THE AGE OF ADULTS ON THE MORPHOMETRICS OF HONEY BEES (APIS MELLIFERA L.)
}

\author{
E.W. HERBERT, $\mathrm{Jr}_{\mathrm{r}}^{*}$, H.A. SYLVESTER **, J.D. VANDENBERG * and H. SHIMANUKI * \\ * Beneficial Insects Laboratory, U.S. Department of Agriculture, ARS, Beltsville, MD 20705 \\ ** Honey Bee Breeding, Genetics, and Physiology Laboratory, U.S. Department of Agriculture, ARS, \\ Baton Rouge, LA 70808
}

\begin{abstract}
The effect of nutritional stress, and the post-emergence age of adult worker honey bees, on the morphometric determinations used to distinguish between Africanized and European honey bees were studied. Small nucleus colonies of bees in cages were fed either pollen, a defined synthetic diet, or a pollen substitute. Four free-flying colonies of bees were used as controls. Bees fed the various diets were all identified as European when samples of 10 bees were analyzed. However, there were individual bees in some treatments which were identified as Africanized with a probability of 0.50 or greater. Age was shown to influence results of morphometric analysis : samples of very young bees (less than 1 min post emergence) were more variable in their measurements than older bees $(1,6,12,24$ or $48 \mathrm{~h}$ post emergence).
\end{abstract}

\section{INTRODUCTION}

Hybrids of the African honey bee, Apis mellifera scutellata, and European races, are continuing their northern movement towards the U.S. and are predicted to reach the U.S. - Mexican border within the next few years. The undesirable characteristics of these bees have been documented in the literature by a number of researchers (Michener, 1975 ; TAYLOR, 1985 ; Rinderer, 1986 ; Dietz et al., 1986 ; DANKa and Rinderer, 1986). Their increased defensiveness, swarming, and absconding behavior will make them unwelcome to the general public and beekeepers.

Africanized and European honey bees are similar in size but Africanized honey bees are slightly smaller with average worker cell diameters of 4.8$4.9 \mathrm{~mm}$ versus $5.2-5.3 \mathrm{~mm}$ for European bees (Rinderer et al., 1982). Experienced beekeepers frequently recognize Africanized bees by their group behavior and the location and features of their colonies. Individual worker bees, or 
small collections of bees, cannot be reliably identified by sight. This makes positive identification of these bees difficult, especially if hybridization occurs.

At present, three methods are being used with varying degrees of success to distinguish between European and African bees and their hybrids. The earliest method developed (Daly and Balling, 1978 ; Daly et al., 1982) involved the measurement of 25 characteristics from the right fore- and hindwings, right hind leg, and the third metasomal sternum of adult workers. The data were then analyzed using a computer-assisted discriminant analysis program. Using all 25 characters gave $100 \%$ separation between the original collections of Africanized and European honey bees. The same procedure can be applied to individual bees but with a higher risk of misclassification (DALY and BALLING, 1978). A further modification of morphometrics was developed by the USDA for rapid field identifications. This identification system was named FABIS-Fast Africanized Bee Identification System. (RINDERER et al., 1986 ; SYLVESTER and RINDERER, 1987).

A second method of identification involves the use of electrophoresis to measure allozymes (Sylvester, 1982). At present, this method is limited to the enzyme malate dehydrogenase. The malate dehydrogenase allozyme pattern of the bees in question is compared with established allozyme patterns from Africanized and European stocks.

The third method of identification involves the analysis of cuticular hydrocarbons from adult bees using gas chromatography and mass spectrometry. Honey bees from South Africa and Africanized bees from Brazil had a substantially higher proportion of C35 unsaturated hydrocarbons than bees of European origin (Francis et al., 1985).

At present, only morphometrics is used by the USDA for differentiating Africanized from the European honey bee races. In order for this method to be broadly applicable, however, the effects of various environmental factors must be known. Unusual environmental stresses such as the quality and quantity of food may alter the normal growth of European bees so that they become smaller adults and thus resemble Africanized bees in some measurements. We report here the results of a study in which known European bees fed diets of varying nutritive value were measured morphometrically using the discriminant analysis program to determine the influence of diet on the resultant body measurements. Additional studies were undertaken to determine the effect of the post-emergence age of young adult worker honey bees on the morphometric measurements. The collection of adult bees before their wings have fully expanded and hardened could result in the misidentification of some samples. 


\section{MATERIALS AND METHODS}

Small nucleus colonies of bees in cages were fed either pollen, a defined synthetic diet, or a pollen substitute (ad libitum). All caged colonies received water and sucrose solution $(50 \% \mathrm{w} / \mathrm{v})$. Four freeflying colonies of honey bees were used as controls and were not fed during the study. Pollen used to fced the caged bees was collected each week using front-mounted pollen traps on additional free-flying colonies maintained at Beltsville, MD.

The defined synthetic diet (Herbert and Shimanuki, 1977) contained ten essential and eight nonessential amino acids, sucrose, B-vitamins (eight B-vitamins plus choline chloride and inositol) and a salt mixture. The pollen substitute (Herbert and Shimanukı, 1980) contained lactalbumin and yeast as the protein sources.

Each type of diet was made available to four colonies of bees by placing $50 \mathrm{~g}$ of diet in a plastic Petri dish lid $(15 \times 100 \mathrm{~mm})$ that was inverted over the top bars of a miniature hive $(23 \times 19 \times 25 \mathrm{~cm})$ used for queen mating. The test colonies were each established with $400 \mathrm{~g}$ of newly emerged Italian bees (ca. 4,000 bees) and a mated laying queen. Each hive contained five drawn shallow combs $(3 \times 16 \times 24 \mathrm{~cm})$ free of any pollen or honey. The colonies were confined in screen flight cages $(2 \times 2 \times 2 \mathrm{~m})$ to prevent the collection of pollen. Two colonies offered the same diet were placed in each cage. As soon as the first sealed brood appeared, and bi-weekly thereafter, the area of sealed cells was estimated using a calibrated grid. Newly emerged adult worker bees $(<2 \mathrm{~h}$ of age) were collected three times from each diet treatment group and immediately placed in vials of $70 \%$ ethanol.

The consumption and brood-rearing data for bees reared in cages were analyzed by two-way analysis of variance, and differences were grouped by week according to Duncan's multiple range test.

In addition to the studies using caged bees, studies were undertaken to determine the morphometrics of adult bees reared in vitro. One- to two-day-old larvae $(0.5-2.0 \mathrm{mg})$ were transferred from worker cells in free flying colonies to wax cups and maintained in the laboratory at $34^{\circ} \mathrm{C}$ and $96 \%$ R.H. They were reared according to the method of Vandenberg and Shimanuki (1987) on a diet composed of royal jelly, water, glucose, fructose, and yeast extract (Rembold and LACKNER, 1981). At cessation of the larval feeding stage the prepupae were transferred to individual pupation dishes and maintained at $34{ }^{\circ} \mathrm{C}$ and $70 \%$ R.H. After reaching the adult stage, the bees were preserved in $70 \%$ ethanol for later analysis.

In a third study, the effect of the age of newly emerged bees on morphometric parameters was determined. A frame of sealed brood was collected from each of four free-flying colonies of honey bees. Bees were collected immediately after emergence and held for either $30 \mathrm{sec}$ or $1 \mathrm{~min}$ ( 40 bees for each period) and then placed in vials of $70 \%$ ethyl alcohol. Additional bees were marked with red paint immediately after emergence. These frames of bees were individually maintained in emerging cages placed in an incubator at $34^{\circ} \mathrm{C}$. A total of 200 bees ( 40 from each time interval) was collected after 1 , $6,12,24$, or $48 \mathrm{~h}$ and placed in alcohol $(10 \mathrm{bees} /$ vial).

Samples of bees from all three studies were refrigerated until they were shipped to the USDA Honey-Bee Breeding, Genetics, and Physiology Laboratory, Baton Rouge, LA, for morphometric measurements. Morphometric analyses were performed on bee samples using the procedure of DALY et al. (1982). Parts of bees (forewing, hindwing, hind leg, and the third abdominal sternum) were mounted on microscope slides, and the images were projected optically onto a digitizer pad connected to a computer. A computer program (DALY et al., 1982) then calculated the various measurements and determined by discriminant analysis whether the bees were likely to be European or Africanized in origin. 


\section{RESULTS}

Brood Rearing and Diet Consumption - The four diet treatments resulted in significant variations in the amount of brood reared (Table 1) and diet consumed (Table 2) by honey bees during the 12-week study. Brood rearing by caged and free-flying bees fed various diets was significantly different with total brood production of $3,335,990,337$, and $382 \mathrm{~cm}^{2}$ for free-flying bees, caged bees fed pollen, a synthetic diet and a pollen substitute, respectively. The brood production by free-flying bees was significantly greater than for bees offered the other treatments. This tremendous difference is of interest and is often referred to as "cage effect». This phenomenon is difficult to define since caged bees were fed the same fresh pollen as that collected by free-flying bees. Also, caged bees never experienced a pollen dearth, since the diet was offered ad libitum. Caged bees fed pollen reared three times as many bees to the sealed stage as bees fed the synthetic diet or the pollen substitute.

As with brood rearing, there were large differences in the amounts of diet consumed. Caged bees fed pollen consumed a total of $630 \mathrm{~g}$ of diet compared to $397 \mathrm{~g}$ and $356 \mathrm{~g}$ for bees fed the synthetic diet and pollen substitute, respectively. No consumption data were collected for the free-flying bees.

Morphometric Determination - The morphometric analyses of the 10-bee samples of honey bees offered various diets are shown in Table 3. All composite samples of ten bees each were identified as European $(P \geqslant 0.90)$ by morphometric analysis, with the exception of the samples described below. One of the four first-cycle, pollen-diet samples was identified as Africanized (PA > 0.99). Three of the four lab diet samples were identified as Africanized $(\mathrm{PA}=1.00)$ while the fourth sample was identified as European $(\mathrm{PE}=0.63)$. There were individual bees in some treatments which were identified as Africanized with a probability of 0.50 or greater (6 of 80 control bees, 18 of 120 bees fed pollen, 16 of 120 bees fed a synthetic diet, 1 of 120 bees fed a pollen substitute, and 26 of 40 laboratory-reared bees).

Many of the bees, particularly those reared in the laboratory, had very soft body parts, especially their wings, and were difficult to mount and measure. Many of these bees also had very short forewings. Therefore, an additional test was conducted to examine the effect of age of bees when collected for identification (Table 4). None of these 28 [10-bee] composite samples were identified as Africanized. However, two of the 1-minute samples had three individual bees with $\mathrm{PA}>0.50$ and had $\mathrm{PE}=0.55$ and $\mathrm{PE}=0.73$ for the 10-bee sample (the other two had PE $=1.00$ ). The next lowest [10bee] composite score was $\mathrm{PE}=0.96$ and the rest all had $\mathrm{PE}>0.98$. Of the total 280 bees, 15 individual bees had PA $>0.50$, with 10 of them in the 30 -sec and 1-min samples and none in the 1-h sample. 

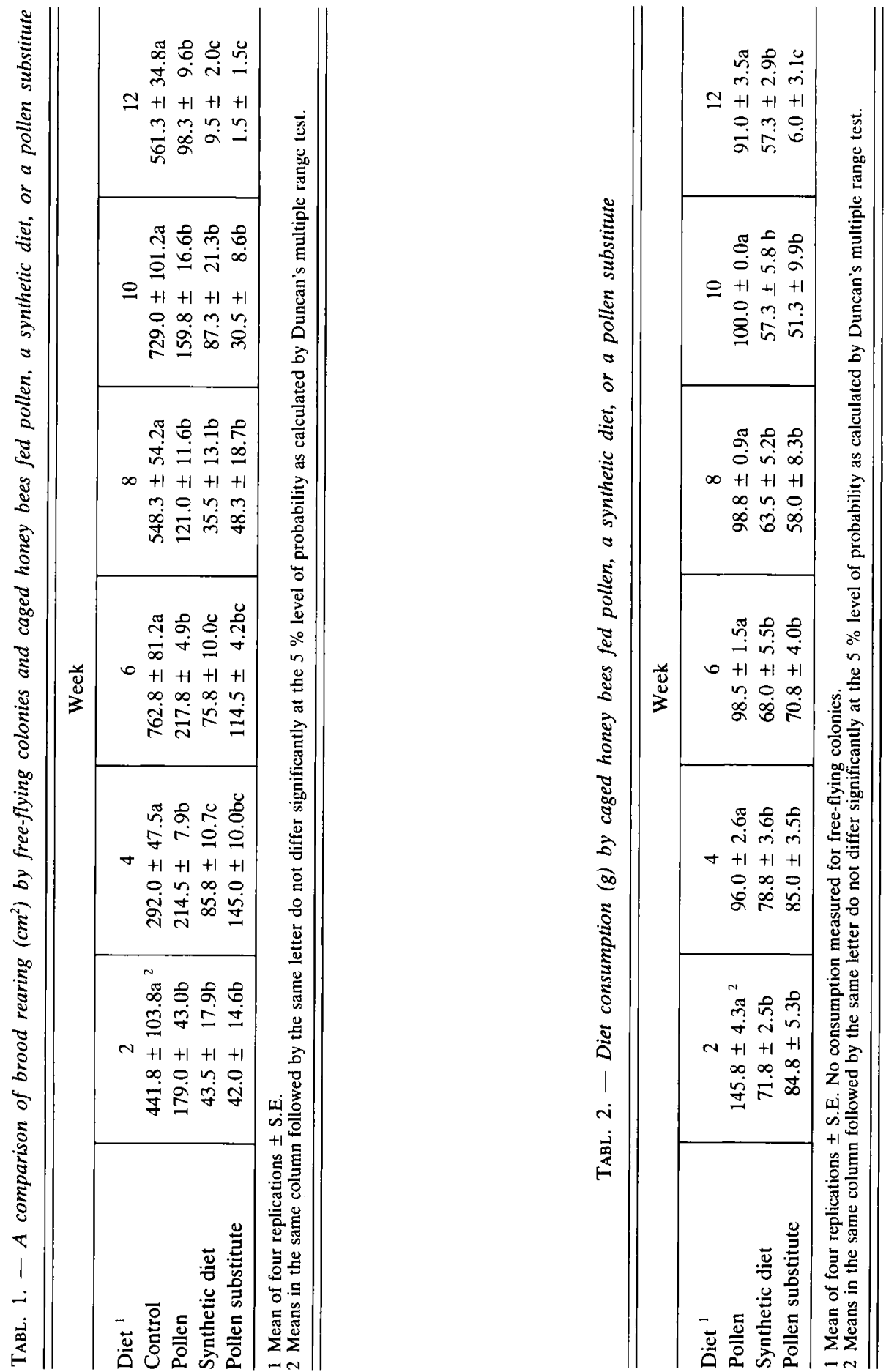
TABL. 3. - Morphometric analysis of 10-bee samples of worker honey bees from colonies fed different diets

\begin{tabular}{|c|c|c|c|c|c|c|c|}
\hline Treatment & $\begin{array}{l}\text { Colony } \\
\text { number }\end{array}$ & $\begin{array}{l}\text { 1st brood } \\
\text { cycle } \mathrm{PE}^{1}\end{array}$ & $\begin{array}{l}\text { Number of } \\
\text { individual } \\
\text { bees with } \\
\text { PA }>0.50\end{array}$ & $\begin{array}{l}\text { 2nd brood } \\
\text { cycle PE }\end{array}$ & $\begin{array}{l}\text { Number of } \\
\text { individual } \\
\text { bees with } \\
\text { PA }>0.50\end{array}$ & $\begin{array}{l}\text { 3rd brood } \\
\text { cycle PE }\end{array}$ & $\begin{array}{l}\text { Number of } \\
\text { individual } \\
\text { bees with } \\
\text { PA }>0.50\end{array}$ \\
\hline Pollen & $\begin{array}{l}1 \\
2 \\
3 \\
4\end{array}$ & $\begin{array}{l}0.99 \\
0.91 \\
0.005 \\
0.92\end{array}$ & $\begin{array}{l}2 \\
3 \\
5 \\
2\end{array}$ & $\begin{array}{l}1.00 \\
1.00 \\
1.00 \\
1.00\end{array}$ & 2 & $\begin{array}{l}0.95 \\
1.00 \\
1.00 \\
0.95\end{array}$ & $\begin{array}{l}3 \\
1\end{array}$ \\
\hline $\begin{array}{l}\text { Pollen } \\
\text { Substitute }\end{array}$ & $\begin{array}{l}1 \\
2 \\
3 \\
4\end{array}$ & $\begin{array}{l}1.00 \\
1.00 \\
1.00 \\
1.00\end{array}$ & & $\begin{array}{l}1.00 \\
1.00 \\
1.00 \\
1.00\end{array}$ & 1 & $\begin{array}{l}1.00 \\
1.00 \\
1.00 \\
1.00\end{array}$ & \\
\hline Synthetic Diet & $\begin{array}{l}1 \\
2 \\
3 \\
4\end{array}$ & $\begin{array}{l}0.94 \\
0.98 \\
1.00 \\
1.00\end{array}$ & $\begin{array}{l}1 \\
2 \\
2 \\
1\end{array}$ & $\begin{array}{l}1.00 \\
1.00 \\
1.00 \\
1.00\end{array}$ & $\begin{array}{l}2 \\
3 \\
1\end{array}$ & $\begin{array}{l}1.00 \\
0.96 \\
1.00 \\
1.00\end{array}$ & $\begin{array}{l}3 \\
1\end{array}$ \\
\hline $\begin{array}{l}\text { Free-flying } \\
\text { Controls }\end{array}$ & $\begin{array}{l}1 \\
2 \\
3 \\
4\end{array}$ & $\begin{array}{l}1.00 \\
1.00 \\
1.00 \\
0.89\end{array}$ & $\begin{array}{l}1 \\
4\end{array}$ & $\begin{array}{l}1.00 \\
1.00 \\
0.99 \\
1.00\end{array}$ & 1 & $\begin{array}{l}\text { These } \\
\text { samples } \\
\text { were } \\
\text { lost }\end{array}$ & \\
\hline $\begin{array}{l}\text { Laboratory } \\
\text { Reared Bees }\end{array}$ & $\begin{array}{l}1 \\
2 \\
3 \\
4\end{array}$ & $\begin{array}{l}0.00 \\
0.63 \\
0.00 \\
0.00\end{array}$ & $\begin{array}{l}8 \\
2 \\
9 \\
7\end{array}$ & & & & \\
\hline
\end{tabular}

$1 \mathrm{PE}=$ probability 10-bee sample is European $(\mathrm{PE}=1-\mathrm{PA})$.

TABL. 4. - Effect of age of adult honey bees on morphometric determination

\begin{tabular}{c|l|l|l|l}
\hline \hline \multicolumn{5}{c}{ Colony number } \\
\hline Age & 1 & 2 & 3 & 4 \\
$30 \mathrm{sec}$ & $1.000^{1}$ & $0.983(1)^{2}$ & 1.000 & $0.999(2)$ \\
$1 \mathrm{~min}$ & $0.554(3)$ & 1.000 & $0.730(3)$ & $1.000(1)$ \\
$1 \mathrm{hr}$ & 1.000 & 0.997 & 0.999 & 0.999 \\
$6 \mathrm{hr}$ & 1.000 & 0.996 & 1.000 & 1.000 \\
$12 \mathrm{hr}$ & 1.000 & $\mathrm{~N} . \mathrm{S}^{3}$ & $0.999(2)$ & $1.000(1)$ \\
$24 \mathrm{hr}$ & $1.000(1)$ & 0.983 & 0.997 & 0.999 \\
$48 \mathrm{hr}$ & $0.969(1)$ & 0.998 & 0.997 & 0.999 \\
\hline
\end{tabular}

1 Probability 10-bee sample is European.

2 Number in parentheses indicates the number of individual bees in the 10-bee sample for which PA $>0.50$.

3 No sample. 


\section{DISCUSSION}

The results of the morphometric analysis and the problems encountered in mounting and measuring body parts indicate that at least some of these bees were probably placed into alcohol too soon, that is before their wings had fully expanded and hardened. This resulted, in many cases, in measured forewing lengths that would be identified as Africanized by the Fast African Bee Identification System (FABIS) (RINDERER et al., 1986). Nevertheless, most of these samples were correctly identified by the procedure of DALY et al. (1982) as European. This further verifies the validity of Daly's procedure in identifying even nutritionally-stressed bees.

The high probabilities of «Africanization » of 26 of the 40 bees reared in the laboratory might be due to rearing conditions. Although adults reared by the method of Vandenberg and Shimanuki (1987) are normal in weight for European bees, their morphometric differences may be due to the size of the larval-rearing containers $(8 \times 10 \mathrm{~mm})$, temperature conditions during feeding, consistency of the food, or to the feeding regime (during which larvae may have been without surplus food at various times). However, these laboratoryreared adults were all dead before being placed in alcohol, and they may have died soon after metamorphosis but before body parts had sufficiently hardened. In particular, the wings probably were not fully expanded and hardened. This would explain why many bees had soft wings which were distorted to varying degrees. Since 16 of the 25 measurements made involve wing lengths or angles, anything which alters the wings could have a major effect on the analysis.

While the test of the effect of age on identification may not appear to be revelant to usual sample collection procedures in the field, it may be quite relevant. Frames from the brood nest may include newly emerged adults. If samples are collected from within the colony by shaking bees from such frames, these bees should not be killed until their exoskeleton has had time to harden. Also, it may be desirable to collect newly emerged bees from frames of emerging brood, to avoid any change of including bees which have drifted from another colony.

In summary, our study showed that diet had virtually no effect on correct identification by morphometrics when a 10-bee sample was used. Using individual bees resulted in less reliable estimates. Age was shown to influence results of morphometric analysis : samples of very young bees were more variable in their measurements. It is important, for morphometric analyses, 


\title{
that young bees less than one-minute post-emergence, be held until their exoskeletons fully expand and harden.
}

Received for publication in December 1987. Accepted for publication in March 1988.

\author{
RÉSUMÉ \\ INFLUENCE DU STRESS ALIMENTAIRE ET DE L'ÂGE DES ABEILLES ADULTES \\ SUR LEUR MORPHOMÉTRIE
}

On a étudié à l'aide d'un programme d'analyse discriminante la morphométrie des abeilles européennes, Apis mellifica ligustica, nourries avec des régimes de valeur nutritive variable, afin de déterminer l'influence du régime sur les mensurations corporelles. Des abeilles européennes ayant subi un stress alimentaire sont susceptibles d'être plus petites et identifiées à tort comme des abeilles africanisées.

De petites colonies d'abeilles maintenues en cage ont reçu soit du pollen, soit un régime synthétique, soit un succédané de pollen. Des ouvrières fraîchement écloses (âgées de moins de $2 \mathrm{~h}$ ) ont été prélevées à 3 reprises et mesurées. Lorsque les mesures ont porté sur 10 abeilles, tous les échantillons ont été correctement identifiés, mais les mesures d'abeilles individuelles ont souvent donné de faux résultats. Des larves âgées de 1 à 2 jours élevées in vitro jusqu'au stage adulte ont donné des abeilles qui ont souvent été identifiées comme africanisées ( 26 sur 40 ). Ces abeilles possédaient des parties très molles, principalement les ailes, et étaient difficiles à monter et à mesurer. On a montré que l'âge des jeunes ouvrières influençait les résultats de l'analyse morphométrique : les échantillons de très jeunes abeilles (moins d'une minute après l'émergence) fournissaient des mesures plus variables que les plus vieilles $(1,6,12$, 24 ou $48 \mathrm{~h}$ après l'émergence). Sur un total de 280 abeilles, 15 abeilles individuelles ont été identifiées comme africanisées avec une probabilité PA $>0,50$. Dix d'entre elles provenaient d'échantillons d'abeilles âgées de $30 \mathrm{sec}$ et d'1 min et aucune de l'échantillon d'abeilles âgées d'1 h. Les ailes n'étaient probablement pas totalement déployées et durcies chez les jeunes abeilles de moins d'1 h. Puisque 16 des 25 mesures effectuées portent sur les longueurs des ailes ou les angles des nervures alaires, tout ce qui peut modifier les ailes est susceptible d'avoir une influence déterminante sur le résultat de l'analyse.

\section{ZUSAMMENFASSUNG}

\section{EINFLUB VON NAHRUNGSSTRESS UND ALTER DER ADULTEN AUF DIE MORPHOMETRIE DER HONIGBIENE}

Europäische Honigbienen, Apis mellifera ligustica, wurden mit Nahrung von verschiedenem Nährwert gefüttert und dann morphometrisch ausgewertet. Es sollte mit Hilfe einer Diskriminanzanalyse der Einfluß der Nahrung auf die resultierenden Körpermaße bestimmt werden. Hinsichtlich der Ernährung gestresste europäische Bienen können kleiner sein und daher unkorrekt als « afrikanisierte " Hybriden eingestuft werden.

Kleinen, in Käfigen gehaltenen Bienenvölkchen, wurde entweder Pollen, eine definierte synthetische Diät, oder ein Pollenersatzmittel gefüttert. Frisch geschlüpfte adulte Arbeitsbienen (weniger als 2 Std. alt) wurden (dreimal pro Diät) gesammelt und morphometrisch bearbeitet. Alle Proben wurden korrekt identifiziert, wenn 10 Bienen gemessen und deren Durchschnitt berechnet wurde ; bei einzelnen Bienen ergaben sich oft falsche Ergebnisse. Ein- bis zwei Tage alte Larven, die in vitro aufgezogen wurden, ergaben ebenfalls oft adulte Bienen, die als afrikanisiert identifiziert wurden (26 von 40 Bienen). Diese Bienen hatten sehr weiche Körperteile (Flügel), waren schwierig zu präparieren und zu messen. 
Das Alter (nach dem Schlupf) der jungen adulten Arbeitsbienen war von großer Bedeutung für das Ergebnis der morphometrischen Analyse : Proben von sehr jungen Bienen (weniger als $1 \mathrm{~min}$. nach dem Schlupf) waren variabler in ihren Meßwerten als Proben von älteren Bienen $(1,6,12,24$ oder 48 Stunden nach dem Schlupf). Von den insgesamt 280 Bienen hatten 15 einzelne Bienen eine Wahrscheinlichkeit von PA $>0.5$ als «afrikanisiert» eingestuft zu werden. Von diesen waren 10 in den Gruppen 30 Sek. und $1 \mathrm{~min}$. nach Schlupf zu finden und keine in der Gruppe 1 Std. (Tab. 4). Die Flügel waren wahrscheinlich bei den frisch geschlüpften Bienen noch nicht voll ausgebreitet und gehärtet. Da 16 der 25 gemessenen Merkmale mit der Flügellänge oder den Aderwinkeln zusammenhängen, wird alles, was die Form des Flügels verändert, einen entscheidenden Einfluß auf das Ergebnis der Analyse haben.

\section{REFERENCES}

Daly H.V., and Balling S.S., 1978. - Identification of Africanized honeybees in the western hemisphere by discriminant analysis. J. Kans. entomol. Soc., 51, 857-869.

Daly H.V., Hoelmer K, Norman P., and Allen T., 1982. - Computer-assisted measurement and identification of honeybees. Ann. Entomol. Soc. Am., 75, 591-594.

Danka R.G., and Rinderer T.E., 1986. - Africanized bees and pollination. Am. Bee J., 126, 680-682.

Dietz A., Krell R., and Petris J., 1986. - The potential limits of survival for Africanized bees in the United States. Proc. Africanized Honey Bee Symposium, Farm Bureau, Atlanta, GA pp. 87-100.

Francis B.R., Blanton W.E., and Nunamaker R.A., 1985. - Extractable surface hydrocarbons of workers and drones of the genus Apis. J. Apic. Res., 24, 13-26.

Herbert E.W. Jr, and ShimanuKı H., 1977. - Brood-rearing capability of caged honeybees fed synthetic diets. J. Apic. Res., 16, 150-153.

Herbert E.W. Jr., and Shimanuki H., 1980. - An Evaluation of seven potential pollen substitutes for honey bees. Am. Bee J., 120, 349-350.

Michener C.D., 1975. - The Brazilian bee problem. Annu. Rev. Entomol., 20, 399-416.

REMBold H., and LACKNer B., 1981. - Rearing of honeybee larvae in vitro : effect of yeast extract on queen differentiation. J. Apic. Res., 20, 165-171.

Rinderer T.E., 1986. - Africanized bees : the Africanized process and potential range in the United States. Bull. Entomol. Soc. Am., 32, 222-227.

Rinderer T.E., Tucker K.W., and Coluns A.M., 1982. - Nest cavity selection by swarms of European and Africanized honeybees. J. Apic. Res., 21, 98-103.

Rinderer T.E., Sylvester H.A., Brown M.A., Villa J.D., Pesante D. and Collins A.M., 1986. Field and simplified techniques for identifying Africanized and European honeybees. Apidologie, 17, 33-48.

Sylvester H.A., 1982. - Electrophoretic identification of Africanized honeybees. J. Apic. Res., 21, 9397.

Sylvester H.A., and Rinderer T.E., 1987. - Fast Africanized bee identification system (FABIS) manual. Am. Bee J., 127, 511-516.

TAylor O.R., 1985. - African bees : potential impact in the United States. Bull. Entomol. Soc. Am., 31, 15-24.

VANDEnberg J.D., and ShimanukI H., 1987. - Technique for rearing worker honeybees in the laboratory. J. Apic. Res., 26 (2), 90-97. 